\title{
Behavior of Ralstonia solanacearum Race 3 Biovar 2 During Latent and Active Infection of Geranium
}

\author{
Jill K. Swanson, Jian Yao, Julie Tans-Kersten, and Caitilyn Allen
}

Department of Plant Pathology, University of Wisconsin-Madison, 1630 Linden Dr., Madison, WI 53706.

Current address of J. Tans-Kersten: State Lab of Hygiene, 465 Henry Mall, Madison, WI 53706.

Accepted for publication 21 September 2004.

\begin{abstract}
Swanson, J. K., Yao, J., Tans-Kersten, J., and Allen, C. 2005. Behavior of Ralstonia solanacearum race 3 biovar 2 during latent and active infection of geranium. Phytopathology 95:136-143.

Southern wilt of geraniums (Pelargonium hortorum), caused by the soilborne bacterium Ralstonia solanacearum race 3 biovar 2 (R3bv2), has inflicted significant economic losses when geranium cuttings latently infected with this quarantine pest were imported into the United States. Little is known about the interaction between $R$. solanacearum and this ornamental host. Using UW551, a virulent R3bv2 geranium isolate from a Kenyan geranium, we characterized development of Southern wilt disease and R3bv2 latent infection on geranium plants. Following soil inoculation, between 12 and $26 \%$ of plants became latently infected, carrying average bacterial populations of $4.8 \times 10^{8} \mathrm{CFU} / \mathrm{g}$ of crown tissue

destructive means of testing pools of asymptomatic plants. Similarly, symptomatic plants shed $2 \times 10^{6} \mathrm{CFU} / \mathrm{ml}$ of run-off water. A few hundred $R$. solanacearum cells introduced directly into geranium stems resulted in death of almost all inoculated plants. However, no disease transmission was detected after contact between wounded leaves. Increasing temperatures to $28^{\circ} \mathrm{C}$ for 2 weeks did not convert all latently infected plants to active disease, although disease development was temperature dependent. Holding plants at $4^{\circ} \mathrm{C}$ for $48 \mathrm{~h}$, a routine practice during geranium cutting shipment, did not increase frequency of latent infections. $R$. solanacearum cells were distributed unevenly in the stems and leaves of both symptomatic and latently infected plants, meaning that random leaf sampling is an unreliable testing method. UW551 also caused potato brown rot and bacterial wilt of tomato, surpassing race 1 strain K60 in virulence on tomato at the relatively cool temperature of $24^{\circ} \mathrm{C}$.
\end{abstract} in the absence of visible symptoms. Such latently infected plants shed an average of $1.3 \times 10^{5} \mathrm{CFU} / \mathrm{ml}$ in soil run-off water, suggesting a non-
Additional keyword: bioterrorism.
Southern wilt of geranium (Pelargonium hortorum) is caused by Ralstonia solanacearum (Smith) Yabuuchi et al., a soilborne bacterium that typically invades plants through the roots and colonizes host xylem vessels. Symptoms include leaf yellowing, wilting, and necrosis, as well as vascular browning. $R$. solanacearum is best known as the cause of bacterial wilt, a disease that affects diverse plants ranging from solanaceous crops like tomatoes and tobacco to peanuts, bananas, ginger, and eucalyptus. The pathogen is widely distributed in tropical and warm-temperate regions, where it causes large crop losses (21). $R$. solanacearum is a species complex, a large heterogenous group of related strains (13). It has been subdivided into races based on host range and biovars based on carbohydrate utilization (21). A phylogenetically and phenotypically homogenous cluster known as race 3 biovar 2 (R3bv2) contains cool-tolerant strains believed to have originated in the Andes (14,31).

R3bv2 strains cause potato brown rot, which ranks among the most destructive diseases of potato in Africa, Asia, and Central and South America (6). The pathogen commonly forms latent (asymptomatic) infections in the cool tropical highlands, but when infected seed tubers are planted in warmer lowland fields, the resulting plants quickly wilt and die (1). R3bv2 was introduced into northern Europe in the late 1980s and caused both economic and political problems when it appeared on potatoes in 1995 (23). Despite ongoing eradication efforts, the bacterium is still present in a number of fields and waterways of northern Europe, although it has caused only minor direct crop losses (11). Recent ecological

Corresponding author: C. Allen; E-mail address: cza@plantpath.wisc.edu

DOI: 10.1094/PHYTO-95-0136

(c) 2005 The American Phytopathological Society studies found that an R3bv2 strain could survive at least 12 months in temperate field soil and for at least 110 days in surface water at $12^{\circ} \mathrm{C}(39,40)$. Although the host range of R3bv2 was once thought to be limited to potatoes, eggplant, and tomato, it is now known that these strains can potentially infect many ornamental and weed species as well $(24,32,38,42)$. Solanum dulcamara, a common semi-aquatic weed, is an important survival refuge and source of inoculum in Europe (10). R3bv2 is not known to be established in North America.

Geraniums sold in Europe and North America are commonly grown from cuttings produced in the highland tropics of Africa and Central America, where R3bv2 is endemic. Southern wilt was reported on U.S. geraniums grown from imported cuttings as early as 1981 (35). The volume of geranium cuttings imported to the United States has grown dramatically, increasing from an estimated 10 million cuttings per year in 1985 to an estimated 100 million in 2003 (M. Klopmeyer, Ball FloraPlant, personal communication). Perhaps not coincidentally, $R$. solanacearum has been repeatedly introduced to Europe and North America in geraniums in recent years $(18,24,27,43)$. Most geranium isolates of $R$. solanacearum that have been classified belong to R3bv2 $(24,27,43)$, though one outbreak was caused by a race 1 biovar 1 strain (33). Southern wilt is a minor disease of geranium, but any introduction of R3bv2 to North America raises concerns because the presence of R3bv 2 on potato could cause quarantine and trade-related losses to the potato industry. R3bv2 was among 10 plant pathogens listed in the Agricultural Bioterrorism Protection Act of 2002, so any finding of this organism in the United States is now subject to the strictest eradication requirements and the most stringent security regulations (28).

In February 2003, R. solanacearum R3bv2 was detected in the United States in geraniums imported from Kenya; later that year 
the pathogen was also found in geraniums from Guatemala and Costa Rica $(3,18)$. The resulting response cost growers and regulators an estimated $\$ 10$ million and involved the destruction of around 5 million plants. To address this outbreak, the Animal and Plant Health Inspection Service (APHIS) prepared a Ralstonia Action Plan specifying measures that growers and regulators must take when race 3-infected plants are detected (2). However, these measures were based on best guesses and reasonable extrapolations from other hosts such as potato, because very little research has been done on the geranium-Ralstonia interaction. The regulatory problem is complicated by the ability of the bacterium to form latent infections, which are difficult to detect but can generate inoculum that leads to disease spread. Understanding R3bv2 pathogenesis and latency in geranium plants is key to designing rapid, accurate diagnostic methods and rational control responses.

We initiated this research to address some of the many unanswered questions about this plant-pathogen interaction. How virulent are R3bv2 strains on geranium? How easily do they form symptomatic and latent infections of this host? What triggers latently infected plants to become actively symptomatic? Is the disease transmitted easily by casual contact during shipping? How is the pathogen distributed in the tissue and rhizosphere of infected plants?

\section{MATERIALS AND METHODS}

Culture conditions and diagnostic testing. $R$. solanacearum strains were grown in casamino acids, peptone, glucose (CPG) broth (22) for rich medium and Boucher's minimal medium (BMM) broth for minimal medium (4). Broth cultures were grown at $28^{\circ} \mathrm{C}$ with $250 \mathrm{rpm}$ agitation for aeration. To grow cultures on solid medium, we used CPG plus $1.8 \%$ agar and $0.05 \%$ 2,3,5-triphenyltetrazolium chloride (TZC) (26). Extracts from plants or effluent were plated on modified semi-selective agar medium (SMSA) (12) containing rifampicin (50 $\mu \mathrm{g} / \mathrm{ml})$ to select UW551-rif; all dilution platings were triplicated. $R$. solanacearum-typical colonies were counted after incubation for 48 to $72 \mathrm{~h}$ at $28^{\circ} \mathrm{C}$. Rapid diagnostic assays were conducted with immunoassay strips specific for $R$. solanacearum according to the manufacturer's instructions (AgDia, Inc., Elkhart, IN). Strains were classified to biovar by inoculating $1 \times 10^{7}$ cells into test tubes filled with $3 \mathrm{ml}$ of Hayward medium containing either $1.0 \%$ glucose, $1.0 \%$ maltose, $1.0 \%$ mannitol, $1.0 \%$ dulcitol, or no carbon source as a negative control (20). A color change from green to yellow after 21 days at $28^{\circ} \mathrm{C}$ indicated the ability of a given strain to produce acid from the carbon source. Diagnostic DNA fragments were amplified by polymerase chain reaction (PCR) using the $R$. solanacearum-specific primer pair 759/760 (5' GTC GCC GTC AAC TCA CTT TCC $3^{\prime}$ and 5' GTC GCC GTC AGC AAT GCG GAA TCG 3') and the race 3-specific primer pair 630/631 (5' ATA CAG AAT TCG ACC GGC AC 3' and 5' ATT CAC ATG CAA TTC GCC TAC $3^{\prime}$ ) as described $(14,30)$.

Bacterial strains. $R$. solanacearum strain UW551 was isolated in February 2003 from the stem of a wilted P. hortorum (geranium) cv. Americana Dark Red plant growing in a Wisconsin greenhouse. The plant had been grown from a cutting shipped from a production facility near Naivasha, Kenya, at an altitude of $2,000 \mathrm{~m}$. Ooze from the stem was streaked on TZC medium and yielded a pure culture of fluidal irregular cream-colored colonies with pink centers; one colony was identified as $R$. solanacearum by diagnostic immunoassay strip. The identity of the isolate was confirmed by $R$. solanacearum-specific PCR and by sequencing of the 16S rDNA gene, which was amplified using universal prokaryotic primers $27 \mathrm{~F}$ and $1492 \mathrm{R}$ (29). This isolate was further classified as R3bv2 by biovar test and race 3-specific PCR, and was named UW551. To allow selection against the bacterial contaminants present in plant material, we created a rifampicin-resistant derivative of UW551 by moving a spontaneous mutation con- ferring rifampicin resistance from strain K60-rif into UW551 by means of natural transformation (25). The resulting strain, UW551-rif, was indistinguishable from its parent in terms of growth in minimal medium, growth in rich medium, biovar test profile, and virulence on tomatoes and geraniums. Control strains for virulence, biovar, and PCR analyses were $R$. solanacearum strains K60 (R1bv1) (26); GMI1000 (R1bv3) (4); UW141 (R1bv4); UW143 (R1bv3); UW145 (R3bv2); UW344 (R3bv2); UW361 (R1bv5); Erwinia carotovora subsp. carotovora (WPP1) (46); Xanthomonas hortorum pv. pelargonii (UW553); and Escherichia coli DH5- $\alpha$ (19). Strains without listed references were from the Allen lab strain collection at the University of Wisconsin-Madison.

Host plant inoculations. Virulence assays on tomato (cv. Bonny Best), potato (cv. Russet Norkotah), and tobacco (cv. Bottom Special) were performed by soil-soak inoculation, in which a bacterial suspension was poured over the soil of unwounded plants. To make inoculum, overnight cultures of $R$. solanacearum strains were pelleted and resuspended in water. Dilution plates were used to confirm the inoculum cell densities. Tomato disease progress curves for strains K60 and UW551 at 24 and $28^{\circ} \mathrm{C}$ were measured as previously described (37). Briefly, bacterial suspensions were poured into the soil of 14- to 15-day-old unwounded tomato plants to obtain a final density of $2 \times 10^{7} \mathrm{CFU} / \mathrm{g}$ of soil. Plants were maintained at either $28^{\circ} \mathrm{C} 12$-h light/12-h dark or $24^{\circ} \mathrm{C} 14$-h light $/ 19^{\circ} \mathrm{C} 10$-h dark for 14 days. Plants were assessed daily by a rater blind to strain identity on a scale of 0 to 4 where $0=$ no wilt, $1=1$ to $25 \%$ leaf area wilted, $2=26$ to $50 \%$ wilted, $3=51$ to $75 \%$ wilted, and $4=76$ to $100 \%$ wilted or dead. Sixteen plants were inoculated for each treatment and the entire experiment was repeated three times. Virulence of UW551 on potato and tobacco was confirmed by soil-soak inoculation of 10 potato plants grown from cuttings and five tobacco plants grown from seed. Geranium plants (cv. Americana Dark Red) were grown from rooted geranium cuttings (supplied by Goldsmith Plants, Gilroy, CA). Rooted cuttings were transplanted in their rooting plugs into 4-in.-round pots containing about $80 \mathrm{~g}$ of Scotts seedling potting mix (Scott's, Marysville, $\mathrm{OH}$ ) and were given at least 1 week to recover from transplanting before inoculation. Unless otherwise noted, geraniums were inoculated with strain UW551rif and grown at $24^{\circ} \mathrm{C} 14$-h light $/ 19^{\circ} \mathrm{C} 10$-h dark, environmental conditions that correspond to those found in commercial production. Geranium plants were inoculated by pouring $50 \mathrm{ml}$ of a bacterial cell suspension over the soil, with the exception of the petiole scar inoculation experiment described below. Inoculum cell densities for each experiment are given below.

Quantifying bacteria from plant tissue. To determine the size of $R$. solanacearum populations in geranium plants, we harvested two slices of about $0.1 \mathrm{~g}$ each from the base of the stem just at the soil line (the crown) or from other plant parts as specified below. One slice was tested for presence of $R$. solanacearum using the immunostrip; since the strip's limit of detection is around $10^{5} \mathrm{CFU}$ of bacteria, this allowed rough estimation of bacterial population size for calibration of the dilution plating. The second slice was ground with a mortar and pestle and suspended in $1 \mathrm{ml}$ of water, serially diluted 10-fold in water, and plated on SMSA plus rif agar plates.

Quantifying bacteria in geranium effluent. The size of $R$. solanacearum populations in effluent (run-off) water and crown tissue from inoculated plants was determined using inoculated plants from the temperature effect experiments. Symptomatic plants were visually rated as stage 1 ( 1 to $33 \%$ of leaves yellowed, wilted), stage 2 (34 to $66 \%$ of leaves yellowed or wilted), stage 3 (67 to $100 \%$ of leaves yellowed or wilted), or stage 4 (dead and decaying). To obtain effluent water, geranium pots were placed on two glass stirring rods over a clean petri dish. Water was poured over the soil of the geranium plant until 5 to $15 \mathrm{ml}$ of effluent flowed from the bottom of the pot into the petri dish. Two hun- 
dred fifty microliters of effluent was mixed with $250 \mu$ of AgDia BEB1 immunoassay buffer and after 5 min this mixture was tested with an immunostrip to determine if more than $10^{5} \mathrm{CFU}$ was present. The effluent was then dilution plated on SMSA plus rif. Crown tissue was also harvested, ground, and dilution plated. To study bacterial population sizes in effluent from geranium plants that had no residual bacterial inoculum in their soil, 60 geranium plants were directly inoculated in the stem. A lower leaf was snapped off at the stem, generating an open wound where the petiole had been attached (petiole scar). A 2- $\mu \mathrm{l} R$. solanacearum suspension containing either 180 cells (30 plants) or 1,800 cells (30 plants) was applied to the petiole scar; this droplet was immediately absorbed into the stem. Plants were monitored for wilt symptoms, effluent was collected from plants at various disease stages, and bacteria were enumerated by plating.

Determining $\boldsymbol{R}$. solanacearum distribution in plants. Twelve symptomatic and 12 latently infected, soil-inoculated geranium plants were sampled by randomly taking cross sections of crown tissue, stems, petioles, and flower stalks. Each sample was cut in half lengthwise. One half was used for an immunostrip test, and the other half was weighed, ground with sterile distilled water, and dilution plated on SMSA plus rif. Plant material giving a positive strip test was ground and dilution-plated at $10^{-4}, 10^{-5}$, and $10^{-6}$, and material giving a negative strip test was plated at $10^{-1}$. If no bacteria were detected at $10^{-1}$ dilution, a sample was reported as 0 . If no bacteria were detected at $10^{-4}$ dilution (and no lower dilutions were available), a sample was reported as undetected.

Determining effects of temperature increase on frequency of latent infection. Forty-five geranium plants were soil-inoculated to a final density of $6.25 \times 10^{5} \mathrm{CFU} / \mathrm{g}$ of soil and 45 plants were inoculated to a final density of $6.25 \times 10^{6} \mathrm{CFU} / \mathrm{g}$ of soil. Eight water controls remained uninoculated. After 25 days at $24^{\circ} \mathrm{C} 14$-h light $/ 19^{\circ} \mathrm{C} 10$-h dark, all symptomatic plants were de-

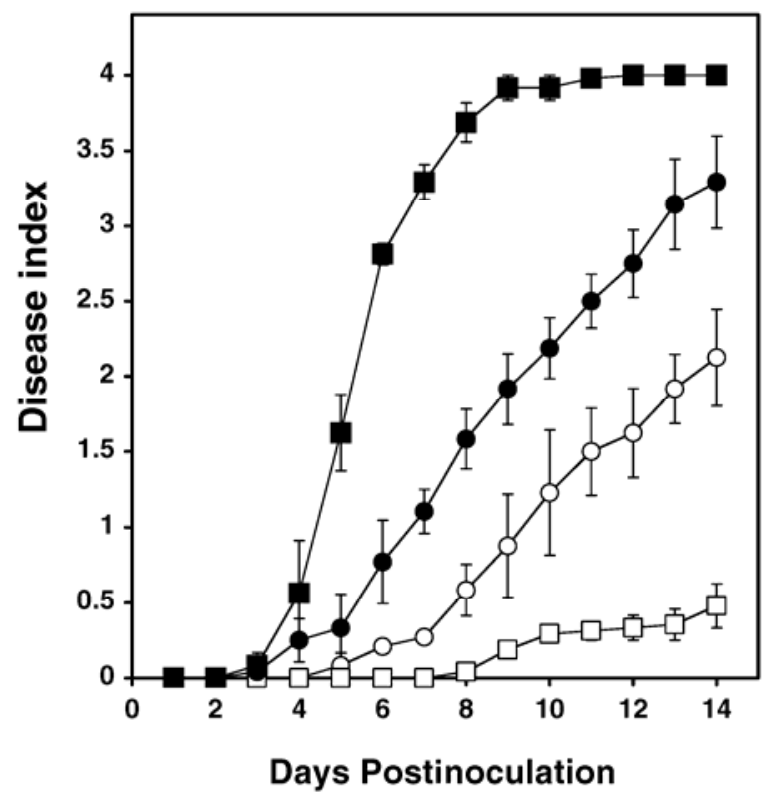

Fig. 1. Disease progress on tomato caused by Ralstonia solanacearum UW551 and $\mathrm{K} 60$ at 24 and $28^{\circ} \mathrm{C}$. Bacterial suspensions were poured over the soil of 15-day-old tomato plants (cv. Bonny Best) to a final density of $3.88 \times$ $10^{7} \mathrm{CFU} / \mathrm{g}$ of soil for race 1 biovar 1 strain $\mathrm{K} 60$ and $3.53 \times 10^{7} \mathrm{CFU} / \mathrm{g}$ of soil for race 3 biovar 2 strain UW551. For each treatment in each replicate, 16 tomato plants were incubated at $24^{\circ} \mathrm{C}$ and 16 were incubated at $28^{\circ} \mathrm{C}$. Disease progress was rated daily for 14 days on a disease index scale of 0 to $4(0=$ no wilt, $1=1$ to $25 \%$ leaves wilted, $2=26$ to $50 \%$ leaves wilted, $3=51$ to $75 \%$ leaves wilted, and $4=76$ to $100 \%$ leaves wilted). Squares represent K60, circles represent UW551, filled symbols represent incubation at $28^{\circ} \mathrm{C}$, and open symbols represent incubation at $24^{\circ} \mathrm{C}$. This graph shows the combined data from three independent experiments; thus, each point represents the mean disease index of 48 plants. Bars represent standard error. stroyed by autoclaving. From the remaining asymptomatic plants, 16 were randomly harvested from each treatment, and their crown tissue was plated as described previously to test for latent infection. The remaining unharvested asymptomatic plants were moved to $28^{\circ} \mathrm{C} 12$-h light/ $12 \mathrm{~h}$-dark. After an additional 14 days at the higher temperature, all diseased plants were destroyed by autoclaving and the asymptomatic plants were harvested and tested for latent infection. This experiment was replicated three times.

Determining effects of temperature decrease on frequency of latent infection. Sixty geranium plants were soil-inoculated to a final density of $4.27 \times 10^{7} \mathrm{CFU} / \mathrm{g}$ of soil. After 48 to $72 \mathrm{~h}$ incubation at $24^{\circ} \mathrm{C} / 19^{\circ} \mathrm{C}, 30$ plants were moved to $4^{\circ} \mathrm{C}$ while 30 control plants remained at $24^{\circ} \mathrm{C} / 19^{\circ} \mathrm{C}$. After $48 \mathrm{~h}$, the plants were moved back to $24^{\circ} \mathrm{C} / 19^{\circ} \mathrm{C}$. All the plants were then monitored for an additional 31 days. After this time, all plants were harvested as described previously. This experiment was replicated three times.

Measuring pathogen transmission via co-mingling of plants. Fifty rooted geranium cuttings, still in their shipping flat, were lightly wounded by running two gloved hands back and forth over them for four passes. A symptomatic wilting geranium was cut from its pot and held by the stem as it was brushed over the geranium cuttings four to five times. The cuttings were then transplanted into 9-oz plastic cups with no drain holes containing moist potting mix and incubated at $24^{\circ} \mathrm{C} 14$-h light $/ 19^{\circ} \mathrm{C} 10-\mathrm{h}$ dark. After 14 days, a $0.1-\mathrm{g}$ slice of crown tissue was removed from each plant and incubated overnight in $3 \mathrm{ml}$ of SMSA broth at $28^{\circ} \mathrm{C}$ with shaking to enrich for $R$. solanacearum cells. One hundred microliters from each tube was spread on duplicate SMSA plus rif plates to detect any $R$. solanacearum colonies. Stems were considered positive if the broth was cloudy or if any $R$. solanacearum colonies grew on the SMSA plates. This experiment was replicated three times.

\section{RESULTS}

$R$. solanacearum UW551 is a virulent R3bv2 isolate. $R$. solanacearum strain UW551 was isolated from a wilting geranium plant derived from cuttings shipped from Kenya, which is the presumed origin of this isolate. PCR amplification of a race 3-specific band (13) and the biochemical biovar test (20) both indicated that UW551 belonged to R3bv2 (data not shown). UW551 has a broad profile of antibiotic resistances. It is fully resistant to ampicillin at $25 \mu \mathrm{g} / \mathrm{ml}$, chloramphenicol at $50 \mu \mathrm{g} / \mathrm{ml}$, gentamycin at $50 \mu \mathrm{g} / \mathrm{ml}$, streptomycin at $60 \mu \mathrm{g} / \mathrm{ml}$, and spectinomycin at $20 \mu \mathrm{g} / \mathrm{ml}$; it had partial resistance (slow growth) on ampicillin at $50 \mu \mathrm{g} / \mathrm{ml}$ and kanamycin at $12.5 \mu \mathrm{g} / \mathrm{ml}$. UW551 was pathogenic on geranium, potato, and tomato, but not on tobacco (data not shown). R3bv2 strains of $R$. solanacearum are considered more cold tolerant than race 1 strains (9). To compare the effect of temperature on virulence of R3bv2 strain UW551 and R1bv1 strain $\mathrm{K} 60$, we inoculated tomato plants by soil-soak and incubated them at either 24 or $28^{\circ} \mathrm{C}$. At the warmer temperature, strain K60 killed all plants by 12 days after inoculation, whereas UW551 never caused $100 \%$ disease. At $24^{\circ} \mathrm{C}$, both strains caused less disease on tomato than at $28^{\circ} \mathrm{C}$; however, UW551 generated a significantly higher mean disease index than K60 at the cooler temperature (Fig. 1).

$R$. solanacearum commonly forms latent infections on geraniums. Following each of our soil-soak inoculations of geranium plants, we identified a significant number of plants that had no detectable Southern wilt symptoms but contained large populations of $R$. solanacearum in their crown tissue (the area just above the soil line where the stem transitions to root). These were classified as latently infected. In multiple experiments in which geranium plants were inoculated with $1 \times 10^{7}$ to $5 \times 10^{7} \mathrm{CFU} / \mathrm{g}$ of soil and incubated at $24^{\circ} \mathrm{C}$, an average of approximately $20 \%$ of the plants became latently infected. However, the proportion of plants that developed active infections, latent infections, and those that 
remained uninfected varied considerably across experiments. Latently infected geraniums generally carried large populations of bacteria in their crown tissue, averaging $4.8 \times 10^{8} \mathrm{CFU} / \mathrm{g}$ (Fig. 2). These numbers were comparable to the populations found in the crowns of actively symptomatic geraniums (Fig. 2). We rarely observed more than $60 \%$ symptomatic plants, suggesting that under our inoculation conditions $R$. solanacearum was not an especially aggressive pathogen of geraniums. This result is in agreement with reports from geranium growers, who have not experienced serious direct losses to Southern wilt disease (M. Klopmeyer, Ball FloraPlant and D. Snow, Goldsmith Plants, personal communication).

Geranium plants infected with $R$. solanacearum shed large numbers of bacteria from their roots. $S$. dulcamara plants infected with $R$. solanacearum R3bv 2 shed bacteria abundantly from their roots (10). To test the hypothesis that both geraniums showing disease symptoms and geraniums that were latently infected would have high bacterial populations in their effluent, we dilution-plated run-off water from the pots of both symptomatic and asymptomatic geranium plants. Any plant containing more than $10 \mathrm{CFU}$ of $R$. solanacearum per gram of crown tissue was considered infected. In practice, the distribution of population sizes in plants was bimodal; nearly all plants contained either no detectable $R$. solanacearum cells or more than $10^{5} \mathrm{CFU} / \mathrm{g}$ of crown tissue. Latently infected plants generated significantly larger effluent populations than uninfected plants, and diseased plants generated the highest effluent populations (Fig. 2A). Overall, the soil run-off water from both symptomatic and latently infected geraniums contained large numbers of bacteria. Latently infected plants shed an average of $1.3 \times 10^{5} \mathrm{CFU} / \mathrm{ml}$ of effluent, while symptomatic plants shed an average of $2 \times 10^{6} \mathrm{CFU} / \mathrm{ml}$ of effluent (Fig. 2A). As disease symptoms progressed and the geraniums began to die and decay, the bacterial populations inside the plant decreased sharply, but the effluent populations remained relatively large. To verify that the numbers of bacteria we ob- served in effluent were not due to residual soil-inhabiting $R$. solanacearum cells left from the initial soil-soak inoculation, we inoculated plants directly into the stem with either 180 or 1,800 CFU. This direct introduction of $R$. solanacearum into the plant's vascular system generated no latently infected plants: 59 out of 60 inoculated plants developed symptomatic infections and the one asymptomatic plant contained no detectable bacteria 86 days after inoculation. However, these directly inoculated plants generated bacterial populations in their effluent water as large as those collected from soil-soak inoculated plants (Fig. 2B), suggesting that the effluent population sizes shown in Figure 2A derive primarily from the infected plant, not from residual inoculum in the soil.

Increasing temperature did not reliably convert latent infections of geranium into active symptomatic disease. To test the hypothesis that increasing temperatures will trigger symptoms and thus identify all latently infected geranium plants, we inoculated 45 geranium cuttings for each experiment with UW551-rif and incubated the plants at $24^{\circ} \mathrm{C} 14-\mathrm{h}$ day $/ 19^{\circ} \mathrm{C} 10$-h night. After 25 days, emergence of new disease had leveled off. At this point all diseased plants were discarded, and a random sample of 16 asymptomatic plants were harvested and tested for latent infection to determine the baseline frequency of latent infection. The remaining plants were maintained at $28^{\circ} \mathrm{C}$ for 14 days to significantly exceed the time-temperature guidelines stipulated in the 2003 APHIS Ralstonia Action Plan (2), and then all remaining geraniums were harvested and tested for latent infection. This increase in ambient temperature was followed by wilting of many previously asymptomatic geranium plants, confirming the importance of temperature in Southern wilt disease development (Fig. 3). However, after 14 days at $28^{\circ} \mathrm{C}$ there were still asymptomatic plants that harbored large numbers of bacteria in their crown tissue.

Exposing geranium plants to cold temperatures postinoculation did not increase frequency of latent infection. To reduce spoilage, geranium cuttings are chilled to about $4{ }^{\circ} \mathrm{C}$ immediately
A

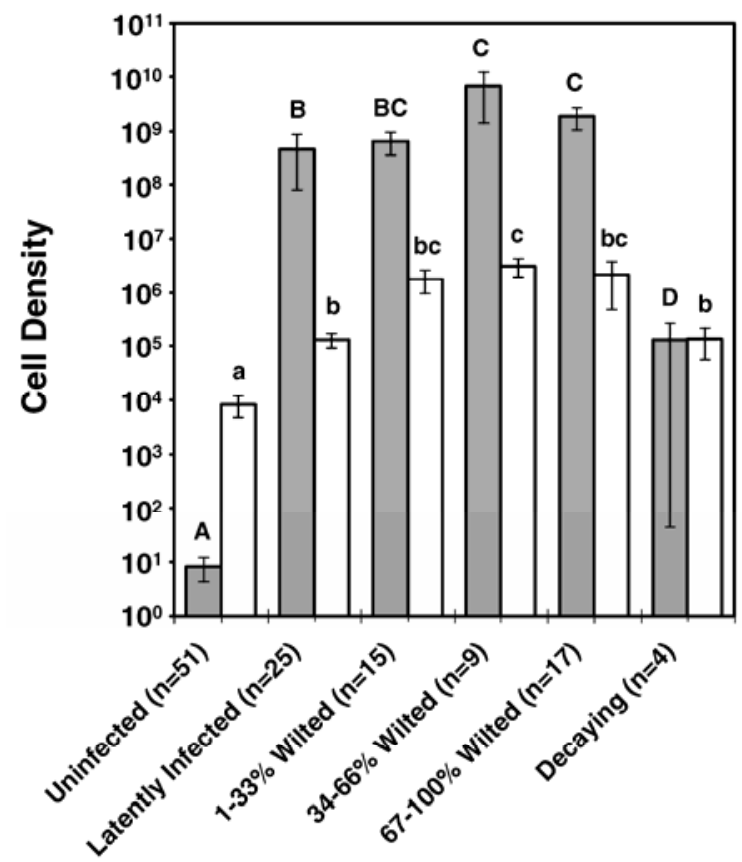

B

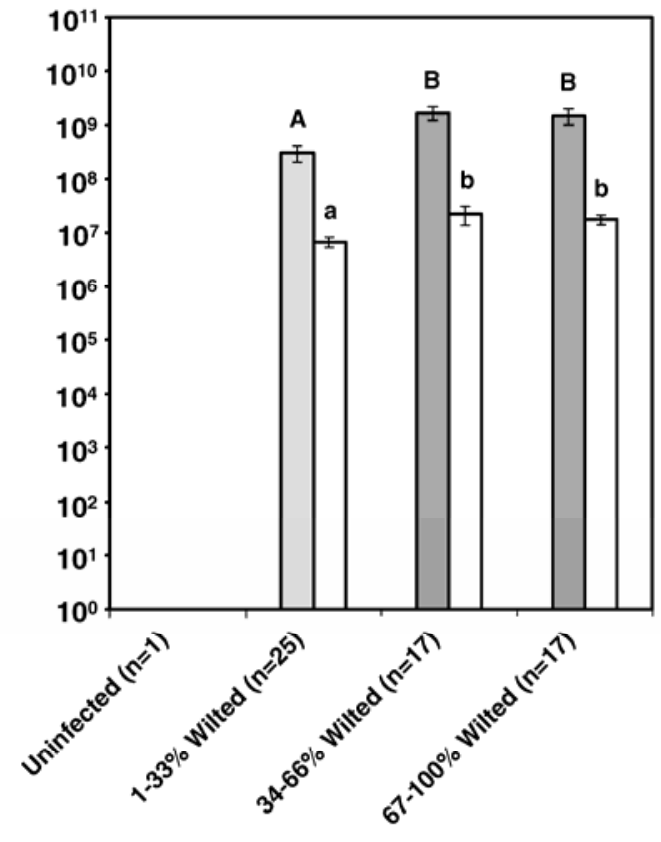

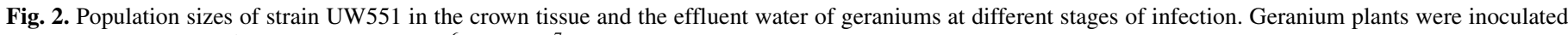

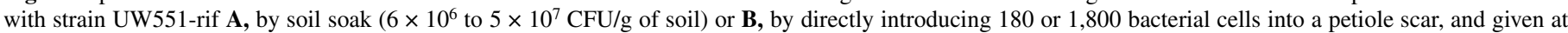

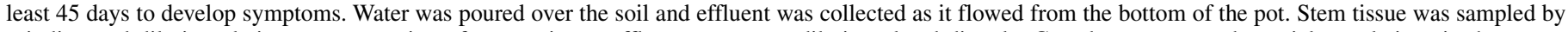

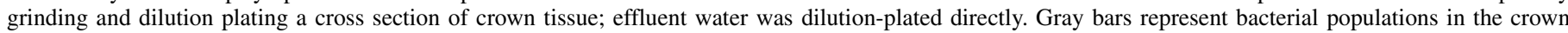

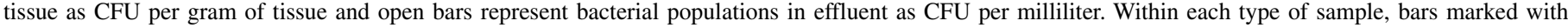

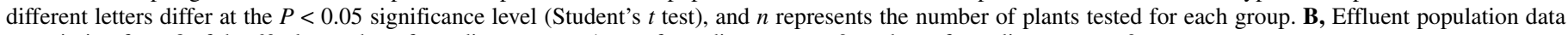
are missing from 8 of the 60 plants: three from disease stage 1, two from disease stage 2, and two from disease stage 3 . 
after harvest and held at this temperature when possible during shipping and while awaiting quarantine inspection at port in the United States; this process takes approximately 2 days. To test the hypothesis that brief exposure to low temperatures increases likelihood of latent infection, we inoculated geranium plants with $R$. solanacearum UW551-rif and incubated them at $24^{\circ} \mathrm{C} 14-\mathrm{h}$ day $/ 19^{\circ} \mathrm{C} 10$-h night for 48 to $72 \mathrm{~h}$. Half the plants were then transferred to $4^{\circ} \mathrm{C}$ (without light) for $48 \mathrm{~h}$ and then returned to $24^{\circ} \mathrm{C} / 19^{\circ} \mathrm{C}$. Thirty-five days after inoculation, all the plants were tested for latent infection. We found no significant differences in the proportion of latently infected plants between the coldshocked group and the untreated group (Fig. 4). This result suggests that current shipping and handling practices involving holding geranium cuttings at low temperatures do not increase the likelihood that $R$. solanacearum-infected plants will develop latent rather than symptomatic infections.

$R$. solanacearum was distributed variably throughout aboveground parts of symptomatic and latently infected geraniums. We observed that Southern wilt symptoms often develop on one side of a geranium plant well before the other side shows disease. To test the hypothesis that this pathogen is not uniformly distributed in its host, we took tissue samples from various parts of symptomatic and latently infected geranium plants, ground them and dilution plated them to measure bacterial population size in each plant part. Samples were taken from symptomatic petioles, healthy petioles, stem tissue, crown tissue, and flower stalks. The plant was considered infected if the crown tissue contained significant populations of $R$. solanacearum. However, the density and presence of R3bv2 in different parts of symptomatic geraniums was highly variable (Fig. 5A). Within a single plant, some tissue samples contained no detectable bacteria while other parts carried large populations. Similar results were found for the latently infected plants (Fig. 5B), although among these plants a larger proportion of sites contained zero or no detectable bacteria. This result demonstrated that sampling for bacteria by removing random stem pieces or petioles is not a reliable method of diagnosing $R$. solanacearum infections of geranium.

Southern wilt does not spread via casual contact between above-ground geranium plant parts. The 2003 USDA-APHIS action plan for dealing with the $R$. solanacearum R3bv2 outbreak in American greenhouses involved an initial hold order and eventually destruction of all plants that had been "co-mingled" with suspect plants; these included any that had been within $1 \mathrm{~m}$ of symptomatic geraniums and any plants that "may have come into contact with suspect geraniums during shipping" (2). To study the frequency of disease transmission between geranium cuttings after casual contact, we simulated the minor wounds and plant-to-plant contact likely to occur during shipping by brushing a wilting geranium plant (infected with UW551-rif) several times over the leaves of lightly damaged, rooted, geranium cuttings still

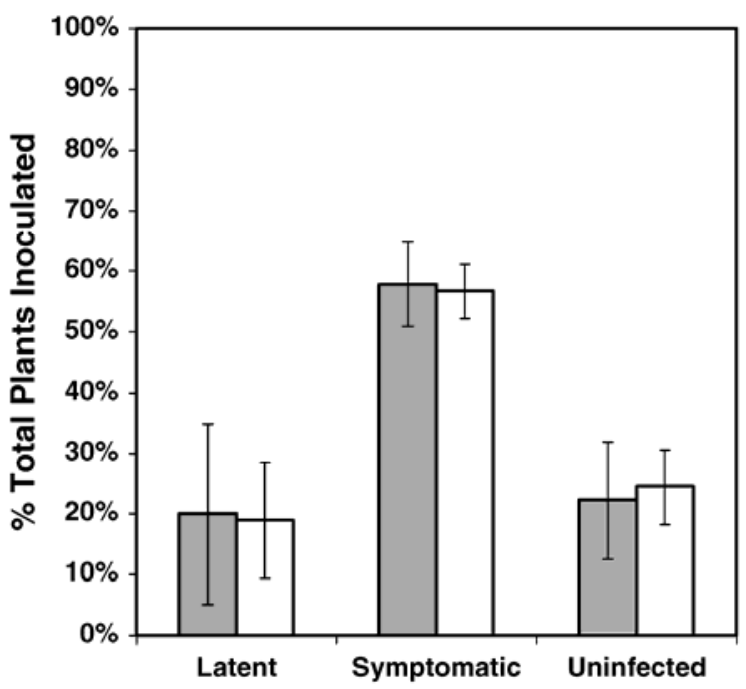

Fig. 4. Effect of cold shock on latent infections. Sixty geranium plants were inoculated with Ralstonia solanacearum UW551-rif to a final concentration of about $4 \times 10^{7} \mathrm{CFU} / \mathrm{g}$ of soil. Thirty plants (gray bar) were held at $4{ }^{\circ} \mathrm{C}$ for $48 \mathrm{~h}$ at 2 days postinoculation. The other 30 plants (open bars) received no cold treatment. After 32 to 35 days at $24^{\circ} \mathrm{C} 14$-h light $/ 19^{\circ} \mathrm{C} 10$-h dark, crown tissue of asymptomatic plants was harvested by grinding and dilution plating to determine whether they were latently infected. The graph represents the means of three independent experiments. Bars represent standard error.
A

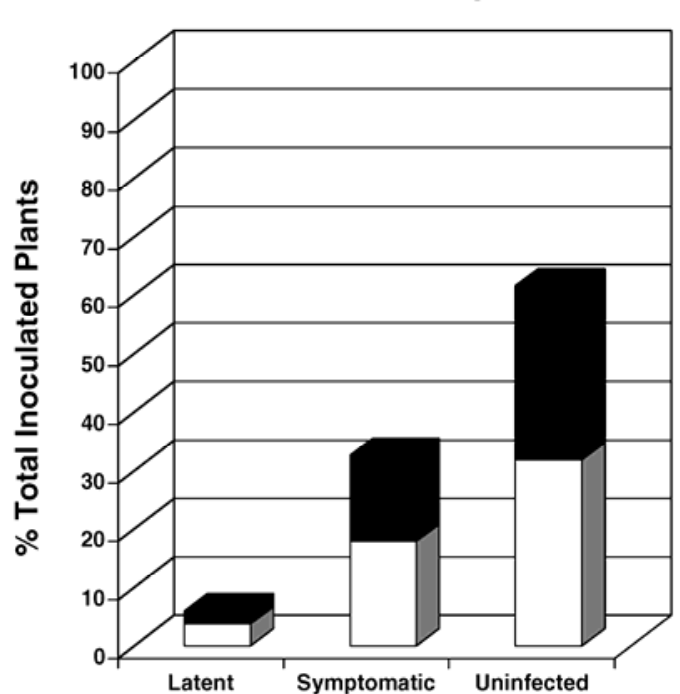

B

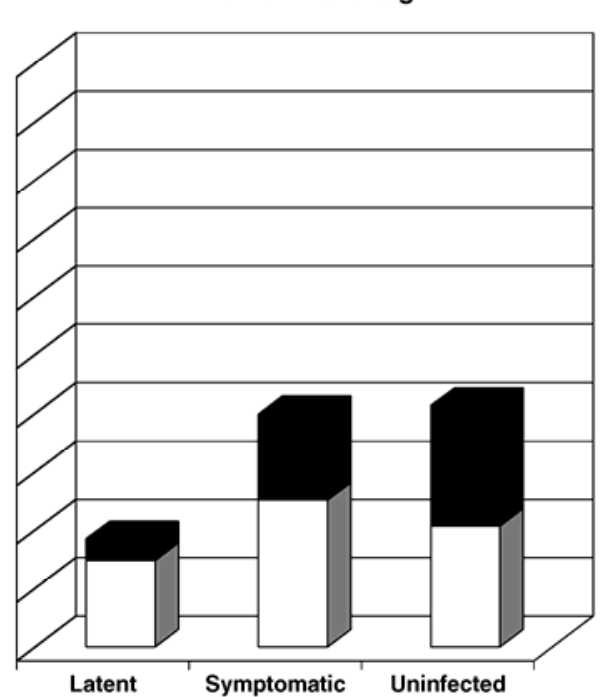

Fig. 3. Effect of increased temperature on latent infections. Forty-five geranium plants were inoculated with Ralstonia solanacearum UW551-rif to a final density of either A, $6.25 \times 10^{5} \mathrm{CFU} / \mathrm{g}$ of soil or $\mathbf{B}, 6.25 \times 10^{6} \mathrm{CFU} / \mathrm{g}$ of soil and incubated at $24^{\circ} \mathrm{C} 14-\mathrm{h}$ light $/ 19^{\circ} \mathrm{C} 10$-h dark. After 25 days, populations in 16 asymptomatic plants were determined and the remaining asymptomatic plants were moved to $28^{\circ} \mathrm{C} 14-\mathrm{h} \mathrm{light} / 28^{\circ} \mathrm{C} 10$-h dark. After 14 additional days, bacterial populations in the remaining asymptomatic plants were measured to identify those latently infected. The graph shows the percentage of total plants inoculated at each inoculum level that became symptomatic, latently infected, and actively infected. Open bars represent plants tested at day 25 and black bars represent plants tested at day 40. The graph shows the result of three independent experiments for each inoculum level. 
in their shipping trays. After 14 days incubation at $24^{\circ} \mathrm{C}$, a slice of crown tissue from each brushed plant was incubated overnight at $28^{\circ} \mathrm{C}$ in modified SMSA enrichment broth, which was then plated on SMSA. We tested a total of 150 cuttings in this manner in three separate experiments and never detected $R$. solanacearum cells in the SMSA broth (data not shown). When slices of stem tissue from symptomatic geraniums were incubated in SMSA broth as a positive control, they invariably resulted in cloudy cultures and produced detectable $R$. solanacearum colonies after plating on TZC agar. We concluded that casual contact between above-ground plant parts did not result in detectable transmission of $R$. solanacearum.

\section{DISCUSSION}

We undertook these studies to better understand the interactions between geranium plants and the Southern wilt pathogen, $R$. solanacearum R3bv2. These interactions are of particular concern for regulatory scientists and geranium producers working to develop detection methods and offshore production standards that will reliably prevent further introductions of this quarantine pathogen on imported geranium cuttings. Our studies demonstrated that interactions between R3bv2 and geraniums are complex, with no single environmental or biological factor explaining latent infections. Moreover, we found that large numbers of the bacterium are shed from the roots of both latently infected and symptomatic geraniums, a finding that identified a worrisome source of pathogen dispersal but also suggested a useful diagnostic method.

Infected but symptomless plants pose a vexing problem for producers of vegetatively propagated plants. This problem of latent infection is exacerbated in the case of geraniums and $R$. so- lanacearum R3bv2 because the pathogen is a highly regulated, zero tolerance quarantine pest in western Europe and North America. In addition, producers and regulatory agencies are confronted by an overwhelming volume of imported cuttings (an estimated 100 million in 2003 in the United States alone). It is therefore of considerable interest to identify the factors that cause $R$. solanacearum to form a latent rather than a symptomatic infection in a geranium plant. Latent infections were common under our experimental conditions, ranging from 12 to $26 \%$ of all inoculated plants. We observed significant variability in the percentage of inoculated plants that developed latent infections across multiple experiments. Frequency of latency appeared to be affected by inoculum density and the age of the geraniums at inoculation, but other as-yet unknown factors must also affect development of latent infections. These may include light duration and intensity, plant nutritional status, and size of plants at the time of inoculation. In addition, host plant genetics probably affect the infection process, although nothing is known about resistance to Southern wilt in geranium. Most host resistance to $R$. solanacearum is quantitative and multigenic, and resistance often results from reduced pathogen colonization (34). The bacterium colonizes stems of susceptible tomato lines more effectively than those of resistant lines, and tubers of resistant potato plants are less likely to be latently infected $(7,17)$; these findings suggest that plant host resistance will also affect frequency of latent infection in geranium.

It was particularly important to investigate the effect of temperature on this pathosystem because it is a key parameter for development of both bacterial wilt disease and latent infection by $R$. solanacearum in other hosts (21). Temperature has been repeatedly shown to influence latent infection of potato tubers by R3bv2, and in particular, high temperatures can trigger development of brown rot disease in the field, unmasking potato plants
A

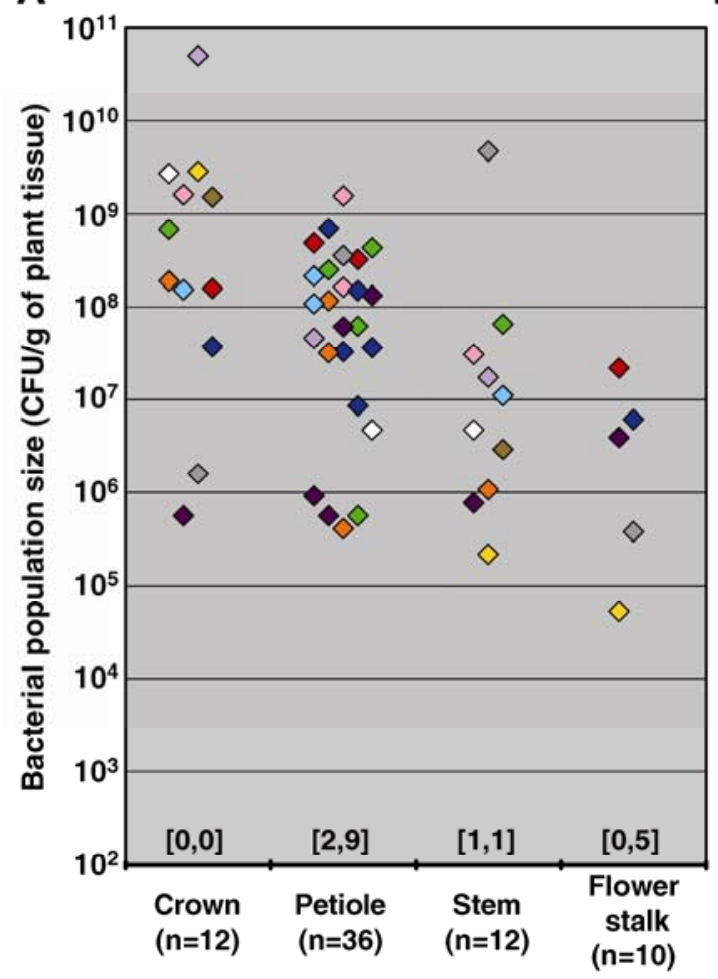

B

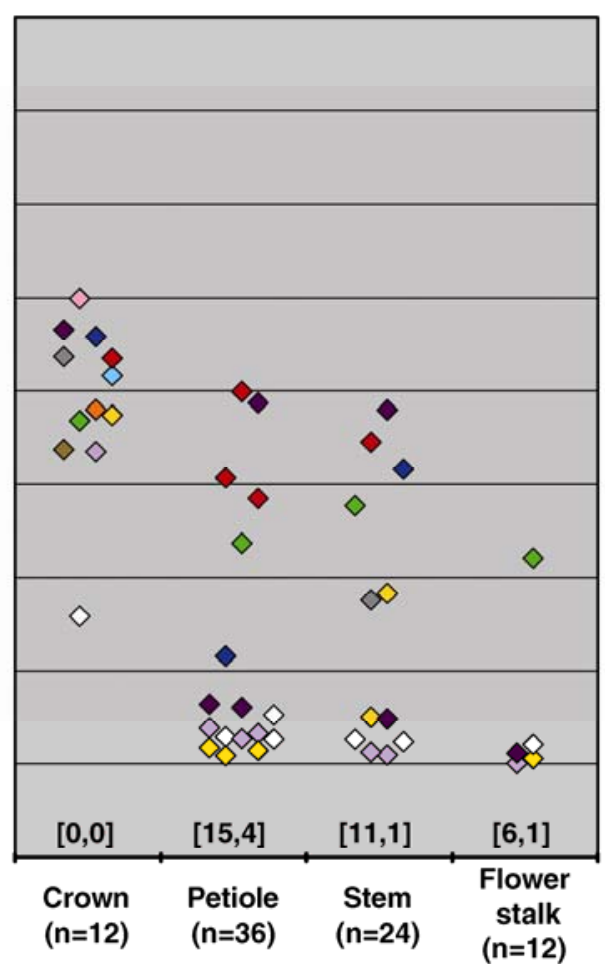

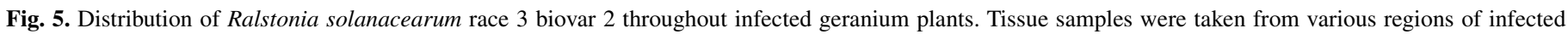

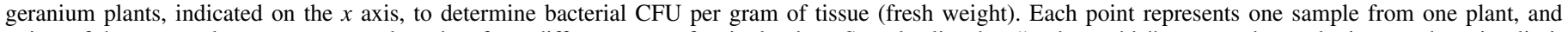

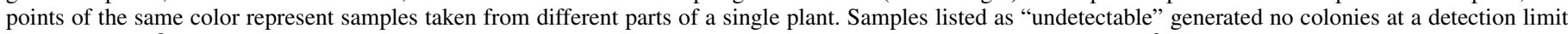

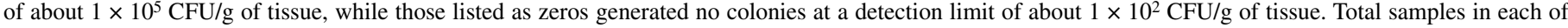

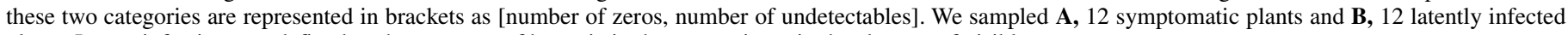
plants. Latent infection was defined as the presence of bacteria in the crown tissue in the absence of visible symptoms. 
latently infected by $R$. solanacearum R3bv2 $(7,9,15,16,21,34,36)$. We found that geranium plants were more susceptible to R3bv2 strain UW551 at $28^{\circ} \mathrm{C}$ than at $24^{\circ} \mathrm{C}$ (data not shown). On tomato plants, UW551 was not as aggressive at $28^{\circ} \mathrm{C}$ as $\mathrm{R} 1 \mathrm{bv} 1$ strain $\mathrm{K} 60$, but it was notably more aggressive than $\mathrm{K} 60$ at $24^{\circ} \mathrm{C}$ (Fig. 1). Similar comparative studies on potato plants also found that R3bv2 strains were more virulent at 16,20 , and $24^{\circ} \mathrm{C}$ than race 1 strains, although the strains caused similar levels of disease at $28^{\circ} \mathrm{C}$ (8). Together, these results support the idea that R3bv2 strains of $R$. solanacearum are better adapted to cause disease at moderately cool temperatures than the more tropical races 1 and 2. However, it should be noted that in our assay, UW551 was not an especially successful tomato pathogen, even on highly susceptible cv. Bonny Best. Neither strain tested killed all tomato plants at $24^{\circ} \mathrm{C}$ and at $28^{\circ} \mathrm{C}$, race 1 strain $\mathrm{K} 60$ was significantly more virulent than UW551 (Fig. 1).

A time-temperature table in the 2003 USDA-APHIS Ralstonia Action Plan required growers to hold geraniums suspected of harboring $R$. solanacearum at warm temperatures for a certain period before they could be released for sale (2). Our results demonstrated that although raising temperatures did generally increase disease incidence in geranium plants inoculated with $R$. solanacearum R3bv2, holding latently infected geranium plants at high temperature for 2 weeks did not reliably cause all latently infected geraniums plants to develop visually detectable symptoms (Fig. 3). Given that there is zero tolerance for this pathogen, this result suggests that it is not useful to place greenhouses containing suspect geraniums under a hold order until they reach an arbitrary time-temperature target.

An interval at low temperature did not affect the course of disease caused by UW551 on geranium. After harvest, geranium cuttings are usually kept at $4^{\circ} \mathrm{C}$ for several days during shipping and inspection. $R$. solanacearum R3bv2 strain 1609 reportedly enters a viable-but-nonculturable state following exposure to $4^{\circ} \mathrm{C}$ in water; cells revived from this state could colonize tomato plants but were no longer virulent (41). However, we found that holding inoculated geranium plants at $4^{\circ} \mathrm{C}$ for $48 \mathrm{~h}$ did not affect frequency of either latent or symptomatic infections (Fig. 4). It should be noted that these bacteria were in soil or plant tissue when exposed to $4^{\circ} \mathrm{C}$, which may have altered their response to low temperature. Moreover, our experiments involved a relatively brief exposure to $4^{\circ} \mathrm{C}$. It is possible that sustained incubation of inoculated geranium plants at slightly warmer temperatures that permit limited bacterial multiplication (such as $16^{\circ} \mathrm{C}$ ) or exposure to $4^{\circ} \mathrm{C}$ at a different time or stage of infection would have a different effect on Southern wilt disease development. Finally, while this experiment was conducted on small geranium plants growing in potting mix, regulatory concerns focus on unrooted cuttings from latently infected plants, which may respond differently to chilling.

We found that latently infected geranium plants and those showing symptoms both shed large numbers of $R$. solanacearum cells from their roots, and that these bacteria could be easily collected and detected in the effluent flowing from their pots (Fig. 2 ). This finding suggests the possibility of a nondestructive, lowtechnology method for testing large numbers of pooled plant samples for latent infection with $R$. solanacearum. Run-off water from many plants could be combined and concentrated by filtration to allow detection of one or a few latently infected plants by commercial immunostrip or PCR. However, our effluent data were obtained from young geranium plants growing in peat-based potting mix. To understand how $R$. solanacearum cells are shed from geranium plants under typical cutting production conditions, these studies should be repeated on large mother plants growing in the volcanic scoria potting medium that is usually used for offshore cutting production. The abundant release of bacteria from roots of infected plants also indicates that ebb-and-flow subirrigation systems can be a very effective means of disseminating this pathogen and should therefore be avoided by geranium producers.
Some plants remained latently infected for at least 120 days under our conditions, suggesting that geraniums may be able to maintain this symptomless but infected condition indefinitely.

Geraniums are propagated vegetatively by rooting developing branches cut from large mother plants. Diagnostic sampling of geranium plants to detect $R$. solanacearum often involves testing a single leaf or stem chosen at random. However, despite its relevance for cutting production and testing, nothing is known about the distribution of $R$. solanacearum in infected plants. We found $R$. solanacearum cells were not uniformly distributed in infected geranium plants, which we defined as carrying bacterial populations of more than $10 \mathrm{CFU} / \mathrm{g}$ of crown tissue. Bacterial populations varied wildly within a single infected plant, ranging from $5 \times 10^{10} \mathrm{CFU} / \mathrm{g}$ of tissue to undetectable (Fig. 5). Symptomatic plants generally had higher populations than latently infected plants, and latently infected plants were more likely to have regions free of the pathogen. However, we also often found parts of symptomatic plants that contained no detectable bacteria. These results indicate that it is inappropriate to randomly test a single geranium stem or leaf for $R$. solanacearum. The patchy distribution of this pathogen in above-ground geranium parts is also consistent with our finding that $R$. solanacearum was not transmitted by casual leaf-to-leaf contact of the kind that occurs during shipping or between plants adjacent on greenhouse benches. In contrast, direct inoculation of the petiole scar on geranium stems with even a few hundred $R$. solanacearum cells quickly killed 59 of the 60 plants tested (the remaining plant was an apparent escape, containing no detectable bacteria). This finding suggests that latent infection and resistance to Southern wilt are circumvented when the pathogen is introduced directly into host xylem tissue rather than invading the plant through roots. Contaminated cutting knives are thus likely to be a very efficient means of pathogen transmission. Growers frequently pinch off developing flower stalks from geranium plants by hand, which could also transmit disease. However, pinching may be slightly less of a threat than infested cutting knives. We detected $R$. solanacearum in only 5 of 10 flower stalks from symptomatic plants and 5 of 12 flower stalks from latently infected plants, which suggests that flower stalks may be less frequently colonized than other above-ground plant parts.

It is of both applied and basic interest to understand how large populations of $R$. solanacearum can live in plant tissue without triggering symptoms. One key to understanding the biology of latency may lie in pathogen gene expression. $R$. solanacearum expresses a subset of its genes specifically during wilt disease development (5). In vivo expression technology or microarray analysis could be used to determine if a different set of bacterial genes are expressed during latent infection than during symptomatic disease. From the other side of the interaction, measuring expression of plant defense genes could reveal whether $R$. solanacearum cells living latently in geranium plants trigger host defense responses. Together with direct studies of such parameters as plant age, cultivar, and temperature, these experiments are needed to elucidate the complex relationship between latent infection by $R$. solanacearum and active Southern wilt disease in geranium plants.

\section{ACKNOWLEDGMENTS}

This research was funded by a USDA Floral and Nursery Industry Task Force Specific Cooperative Agreement and by the University of Wisconsin-Madison College of Agricultural and Life Sciences. We thank D. Thomas (Goldsmith Seeds, Gilroy, CA), M. Klopmeyer (Ball FloraPlant, West Chicago, IL), J. Elphinstone (Central Science Laboratory, York, U.K.), D. Norman (University of Florida), J. Cruse (APHIS, Madison, WI), and D. Kaplan (APHIS-CPHST, Raleigh, NC) for useful discussions and suggestions; B. Hudelson (Wisconsin Plant Disease Diagnostic Clinic) for initial isolation of $R$. solanacearum strain UW551; and AgDia, Inc. (Elkhart, IN) and Goldsmith Plants (Gilroy, CA) for providing research materials. 


\section{LITERATURE CITED}

1. Allen, C., Kelman, A., and French, E. R. 2001. Brown rot of potatoes. Pages11-13 in: Compendium of Potato Diseases. W. R. Stevenson, R. Loria, G. D. Franc, and D. P. Weingartner, eds. The American Phytopathological Society, St. Paul, MN.

2. APHIS-PPQ. 2003. Action plan for Ralstonia solanacearum race 3, biovar 2 found in nursery facilities. Published online by USDA-APHIS PPQ Pest Detection and Management Programs.

3. APHIS-PPQ. 2004. USDA-APHIS pest alert: Ralstonia solanacearum race 3 biovar 2 Southern wilt of geranium. Published online by USDAAPHIS PPQ Pest Detection and Management Programs.

4. Boucher, C., Barberis, P., Trigalet, A., and Demery, D. 1985. Transposon mutagenesis of Pseudomonas solanacearum: Isolation of Tn5-induced avirulent mutants. J. Gen. Microbiol. 131:2449-2457.

5. Brown, D. G., and Allen, C. 2004. Ralstonia solanacearum genes induced during growth in tomato: An inside view of bacterial wilt. Mol. Microbiol. 53:1641-1660.

6. CABI. 2003. CABI Crop Protection Compendium-Global Module (Commonwealth Agriculture Bureau International). 5th ed. CAB International, Wallingford, U.K.

7. Ciampi, L. 1980. Multiplication of Pseudomonas solanacearum in resistant potato plants and the establishment of latent infections. Am. Potato J. 57:319-329.

8. Ciampi, L., and Sequeira, L. 1980. Influence of temperature on virulence of race 3 strains of Pseudomonas solanacearum. Am. Potato J. 57:307-317.

9. Ciampi, L., Sequeira, L., and French, E. R. 1980. Latent infection of potato tubers by Pseudomonas solanacearum. Am. Potato J. 57:377-386.

10. Elphinstone, J. G. 1996. Survival and possibilities for extinction of Pseudomonas solanacearum (Smith) Smith in cool climates. Potato Res. 39:403-410.

11. Elphinstone, J. G. The current bacterial wilt situation: A global overview. In: Bacterial Wilt: The Disease and the Ralstonia solanacearum Species Complex. C. Allen, P. Prior, and A. C. Hayward, eds. The American Phytopathological Society, St. Paul, MN. (In press.)

12. Elphinstone, J. G., Hennessey, J., Wilson, J. K., and Stead, D. E. 1996. Sensitivity of different methods for the detection of Ralstonia solanacearum in potato tuber extracts. EPPO Bull. 26:663-678.

13. Fegan, M., and Prior, P. How complex is the Ralstonia solanacearum species complex? In: Bacterial Wilt: The Disease and the Ralstonia solanacearum Species Complex. C. Allen, P. Prior, and A. C. Hayward, eds. The American Phytopathological Society, St. Paul, MN. (In press.)

14. Fegan, M., Taghavi, M., Sly, L. I., and Hayward, A. C. 1998. Phylogeny, diversity, and molecular diagnostics of Ralstonia solanacearum. Pages 19-33 in: Bacterial Wilt Disease: Molecular and Ecological Aspects. P. Prior, C. Allen, and J. Elphinstone, eds. Springer-Verlag, Berlin.

15. Graham, J., Jones, D. A., and Lloyd, A. B. 1979. Survival of Pseudomonas solanacearum race 3 in plant debris and in latently infected potato tubers. Phytopathology 69:1100-1103.

16. Granada, G. A., and Sequeira, L. 1983. Survival of Pseudomonas solanacearum in soil, rhizosphere, and plant roots. Can. J. Microbiol. 29:433-440.

17. Grimault, V., Anais, G., and Prior, P. 1994. Distribution of Pseudomonas solanacearum in the stem tissues of tomato plants with different levels of resistance to bacterial wilt. Plant Pathol. 43:663-668.

18. Hamrick, D. 2004. Ralstonia strikes American Pelargonium young plants again. FloraCulture International March 14:16-18.

19. Hanahan, D. 1983. Studies on transformation of Escherichia coli with plasmids. J. Mol. Biol. 166:557-580.

20. Hayward, A. C. 1964. Characteristics of Pseudomonas solanacearum. J. Appl. Bacteriol. 27:265-277.

21. Hayward, A. C. 1991. Biology and epidemiology of bacterial wilt caused by Pseudomonas solanacearum. Annu. Rev. Phytopathol. 29:65-87.

22. Hendrick, C., and Sequeira, L. 1984. Lipopolysaccharide-defective mutants of the wilt pathogen Pseudomonas solanacearum. Appl. Environ. Microbiol. 48:94-101.

23. Janse, J. D. 1996. Potato brown rot in western Europe: History, present occurrence and some remarks on possible origin, epidemiology and control strategies. EPPO Bull. 26:679-695.

24. Janse, J. D., van der Beld, H. E., Elphinstone, J., Simpkins, S., Tjou-TamSin, N. A. A., and van Vaerenbergh, J. 2004. Introduction to Europe of Ralstonia solanacearum biovar 2, race 3 in Pelargonium zonale cuttings. J. Plant Pathol. 86:147-155.
25. Kang, Y., Saile, E., Schell, M. A., and Denny, T. P. 1999. Quantitative immunofluorescence of regulated eps gene expression in single cells of Ralstonia solanacearum. Appl. Environ. Microbiol. 65:2356-2362.

26. Kelman, A. 1954. The relationship of pathogenicity of Pseudomonas solanacearum to colony appearance in a tetrazolium medium. Phytopathology 44:693-695.

27. Kim, S. H., Olson, T. N., Schaad, N. W., and Moorman, G. W. 2003. Ralstonia solanacearum race 3 , biovar 2, the casual agent of brown rot of potato, identified in geranium in Pennsylvania, Delaware, and Connecticut. Plant Dis. 87:450.

28. Lambert, C. D. 2002. Agricultural Bioterrorism Protection Act of 2002: Possession, Use, and Transfer of Biological; Agents and Toxins; Interim and Final Rule. (7 CFR Part 331). Federal Register 67(240):76908-76938.

29. Lane, D. J. 1991. 16S/23S rRNA sequencing. Pages 115-175 in: Nucleic Acid Techniques in Bacterial Systematics. E. Stackebrandt and M. Goodfellow, eds. John Wiley \& Sons, New York.

30. Opina, N., Tavner, F., Hollway, G., Wang, J.-F., Li, T.-H., Maghirang, R., Fegan, M., Hayward, A. C., Krishnapillai, V., Hong, W. F., Holloway, B. W., and Timmis, J. 1997. A novel method for development of species and strain-specific DNA probes and PCR primers for identifying Burkholderia solanacearum (formerly Pseudomonas solanacearum). Asia Pacific J. Mol. Biol. Biotech. 5:19-30.

31. Poussier, S., Trigalet-Demery, D., Vandewalle, P., Goffinet, B., Luisetti, J., and Trigalet, A. 2000. Genetic diversity of Ralstonia solanacearum assessed by PCR-RFLP of the hrp region, AFLP and 16S rRNA sequence analysis, and identification of an African subdivision. Microbiology-UK 146:1679-1692.

32. Pradhanang, P. M., Elphinstone, J. G., and Fox, R. T. V. 2000. Identification of crop and weed hosts of Ralstonia solanacearum. Plant Pathol. 19:403-413.

33. Pradhanang, P. M., Momol, M. T., Dankers, H., Momol, E. A., and Jones, J. B. 2002. First report of Southern wilt caused by Ralstonia solanacearum on geranium in Florida. Online. Plant Health Progress doi:10.1094/PHP-2002-0611-01-HN.

34. Prior, P., Allen, C., and Elphinstone, J. (eds.) 1998. Bacterial Wilt Disease: Molecular and Ecological Aspects. Springer-Verlag, Berlin.

35. Strider, D. L., Jones, R. K., and Haygood, R. A. 1981. Southern wilt of geranium caused by Pseudomonas solanacearum. Plant Dis. 65:52-53.

36. Swanepoel, A. 1990. The effect of temperature on the development of wilting and on progeny tuber infection of potatoes inoculated with South African strains of biovar 2 and 3 of Pseudomonas solanacearum. Potato Res. 33:287-290.

37. Tans-Kersten, J., Guan, Y., and Allen, C. 1998. Ralstonia solanacearum pectinmethylesterase is required for growth on methylated pectin but not for bacterial wilt virulence. Appl. Environ. Microbiol. 64:4918-4923.

38. Tusiime, G., Adipala, E., Opio, F., and Bhagsari, A. S. 1998. Weeds as latent hosts of Ralstonia solanacearum in highland Uganda: Implications to development of an integrated control package for bacterial wilt. Pages 413-419 in: Bacterial Wilt Disease: Molecular and Ecological Aspects. P. Prior, C. Allen, and J. Elphinstone, eds. Springer-Verlag, Berlin.

39. van Elsas, J. D., Kastelein, P., de Vries, P. M., and van Overbeek, L. S. 2001. Effects of ecological factors on the survival and physiology of Ralstonia solanacearum bv. 2 in irrigation water. Can. J. Microbiol. 47:842-854.

40. van Elsas, J. D., Kastelein, P., van Bekkum, P., van der Wolf, J. M., de Vries, P., and van Overbeek, L. S. 2000. Survival of Ralstonia solanacearum biovar 2 , the causative agent of potato brown rot, in field and microcosm soils in temperate climates. Phytopathology 90:1358-1366.

41. van Overbeek, L. S., Bergervoet, J. H. W., Jacobs, F. H. H., and van Elsas, J. D. 2004. The low temperature-induced viable but nonculturable state affects the virulence of Ralstonia solanacearum biovar 2. Phytopathology 94:463-69.

42. Wenneker, M., Verdel, M. S. W., Groeneveld, R. M. W., Kempenaar, C., van Beuningen, A. R., and Janse, J. D. 1999. Ralstonia (Pseudomonas) solanacearum race 3 (biovar 2) in surface water and natural weed hosts: First report on stinging nettle (Urtica dioica). Eur. J. Plant Pathol. 105:307-315.

43. Williamson, L., Hudelson, B. D., and Allen, C. 2002. Ralstonia solanacearum strains isolated from geranium belong to race 3 and are pathogenic on potato. Plant Dis. 86:987-991.

44. Yap, M.-N., Barak, J. D., and Charkowski, A. O. 2004. Genomic diversity of Erwinia carotovora subsp. carotovora and its correlation with virulence. Appl. Environ. Microbiol. 70:3013-3023. 